\title{
Report
}

\section{Field trip in the semi-arid Gujarat Alluvial Plain}

\author{
Piotr Gębica' ${ }^{1}$ Lucyna Wachecka-Kotkowska2* , Paweł Kotkowski \\ 'University of Information Technology and Management in Rzeszów, Poland \\ 2Department of Geomorphology and Palaeogeography, University of Łódź, Poland, *lucyna.wachecka@geo.uni.lodz.pl \\ ${ }^{3}$ Veolia Energia Łódź, Poland
}

\begin{abstract}
This report contains short information about the geomorphological field trip in the Gujarat Alluvial Plain. During the field trip the issues of fluvial landform and alluvial deposits of the rivers were discussed: Sabarmathi River, Mahi River, Narmada River and Karjan River. Particular attention was paid to the relief and geological structure of the Gujarat Alluvial Plain, dissected by the valleys of several rivers. The role of tectonics, sea level fluctuations and climate changes and their influence on the course of fluvial, aeolian and sea accumulation in the lower sections of river valleys was emphasized.
\end{abstract}

Key words: bajada, piedmont fan, Gujarat Alluvial Plain, Narmada River, India

One of the post-conference trips after $9^{\text {th }}$ International Conference on Geomorphology in New Delhi (Novemeber 6-11, 2017), entitled B6 Semi-arid Gujarat Alluvial Plain was organized in the state of Gujarat (NW India) on November 12-16, 2017. Seven people took part in it, three from Poland, one from China, Hungary, Romania and the United Kingdom. Accommodation in a hotel in Vadodara, meals and trips to the area were very well organized. Daytime temperatures were $28-32^{\circ} \mathrm{C}$. The program on the first day of the trip included flight to Vadodara and accommodation. On the second day of November 13, the introducing lecture was presented by prof. L.S.Chamyala and prof. D.M.Maurya (Fig. 1) from the Maharaja Sayajirao University of Baroda concerned The Geomorphological evolution of semi-arid Gujarat Alluvial Plain.

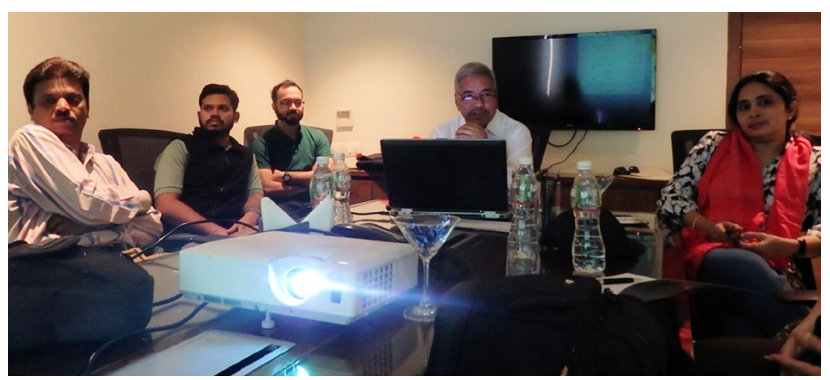

Fig. 1. The Professor L.S.Chamyala's Team (near PC): prof. D.M.Maurya (on the left), dr A.Sridhar (on the right) and assistants (in the background) during the lecture
On the lecture we got acquainted with the geomorphological division and the main types of Gujarat relief. Particular attention was paid to the relief and geological structure of the Gujarat Alluvial Plain, dissected by the valleys of the Sabarmathi, Mahi and Narmada rivers. The role of tectonics, sea level fluctuations and climate changes and their influence on the course of fluvial, aeolian and sea accumulation in the lower sections of river valleys was emphasized (Fig. 2). After the lecture, a trip to the Mahi river valley took place, about $20 \mathrm{~km}$ to $\mathrm{N}$ from Vadodara, and in the following days, there were trips and presentation of profiles in the Narmada River valley and its tributaries.

Narmada is the third largest basin and river flow in the Indian subcontinent with a length of $1310 \mathrm{~km}$. Its middle and upper course falls on the Deccan Plateau built of lava trapp basalt. In the lower section, about $100 \mathrm{~km}$ long, the river crosses the Gujarat alluvial plain and debouch into the Gulf of Cambay (Arabian Sea). The plain is located within the trench tectonic depression. The trench is filled with over $800 \mathrm{~m}$ thick Quaternary deposits, underlain by chalk-Tertiary basaltic lava rocks and basement rocks of the Archaic age (Maurya et al. 1995, Chamyal and Maurya 2017). The sediments forming the plain were deposited in a sedimentary basin undergoing slow subsidence along the active Narmada-Son Fault tectonic fault (NSF) with the course of ENE-WSW and length of over 


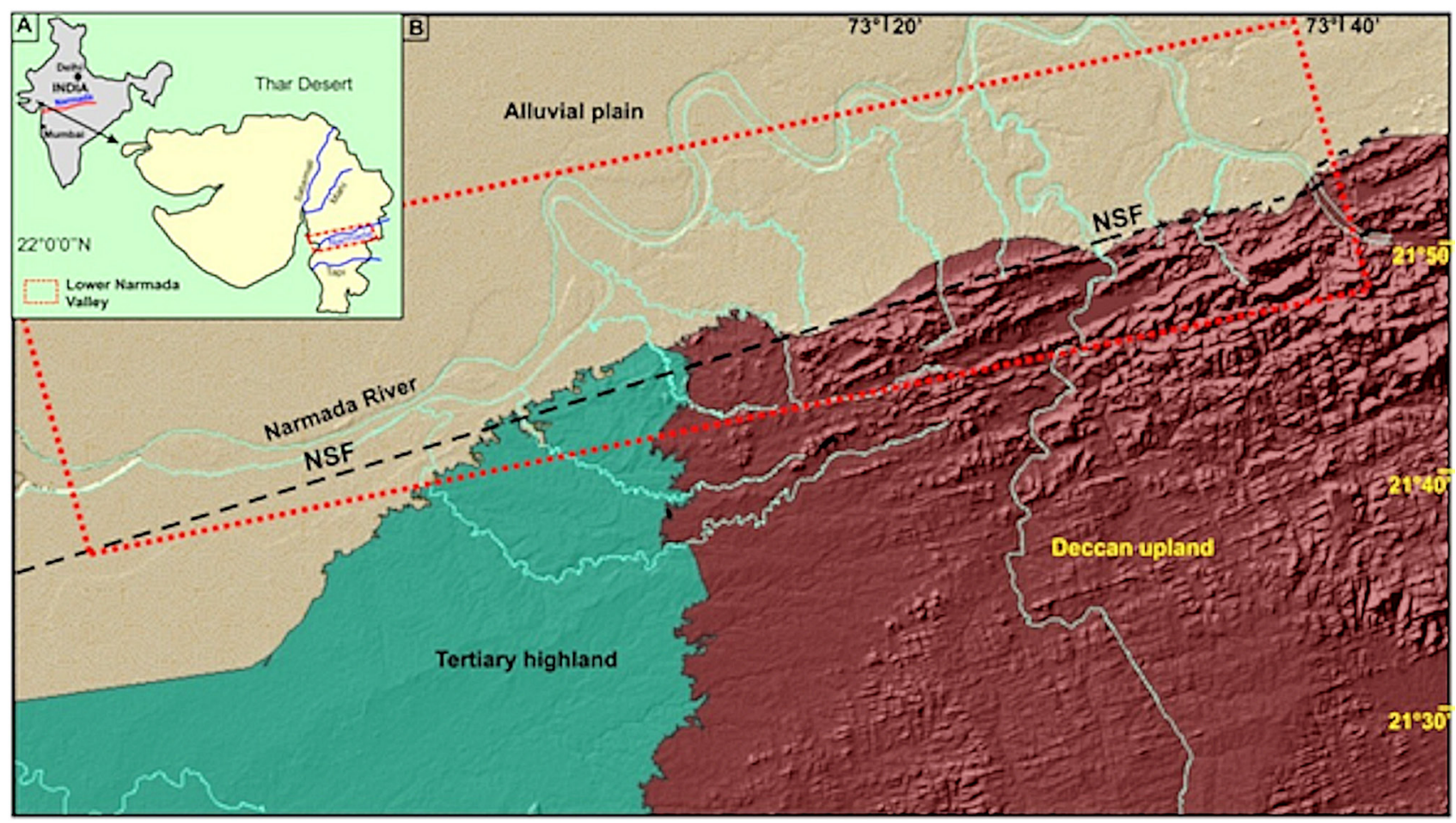

Fig. 2. Location of Gujarat state (A), Lower Narmada and Mahi Rivers system (B); Narmada-Son Fault tectonic fault (NSF) acc. to Joshi et al. (2013)

$1000 \mathrm{~km}$ (Chamyal et al. 2002). The roof part of the basin is filled with $40-50 \mathrm{~m}$ thick alluvium from the Upper (Late) Pleistocene, uncovered as a result of river incision caused by tectonic uplifting of the area in the Early Holocene (Bhandari et al. 2005).

On the Mahi River (November 13) we saw the benchmark profile of terraces from the Upper Pleistocene, 30-meter thick, located about $30 \mathrm{~km}$ from the Arabian Sea. On the Eemian marine clays (MIS$5 e$ - Marine Isotope Stage) lies the lower series of alluvium topped with red soil, on which the upper series of sandy fluvial and aeolian sediments rests (Fig. 3).

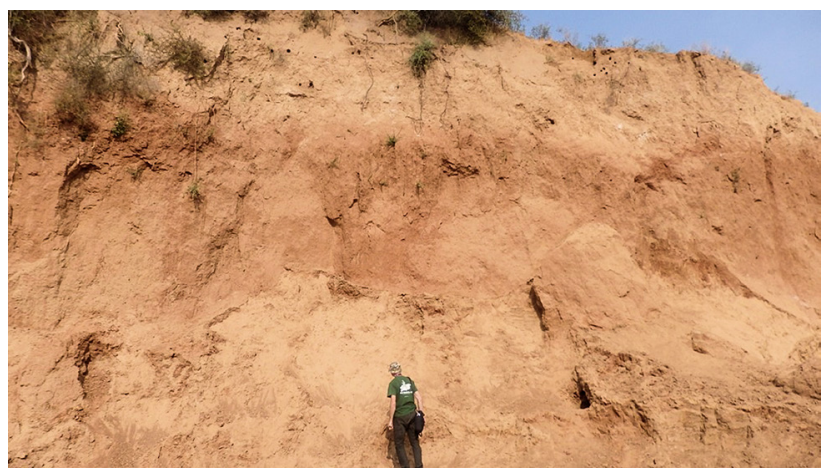

Fig. 3. Rayka section at Mahi River Basin. Late Quaternary Sequences

On the bottom part: basal silty clay, cross stratified gravel; in the middle: silty sand, medium sand and cross stratified gravel (ca. $74 \mathrm{ka}$ ); on the top: pedogenised silty sand, red soil (ca. 68 ka) and aeolian sand.

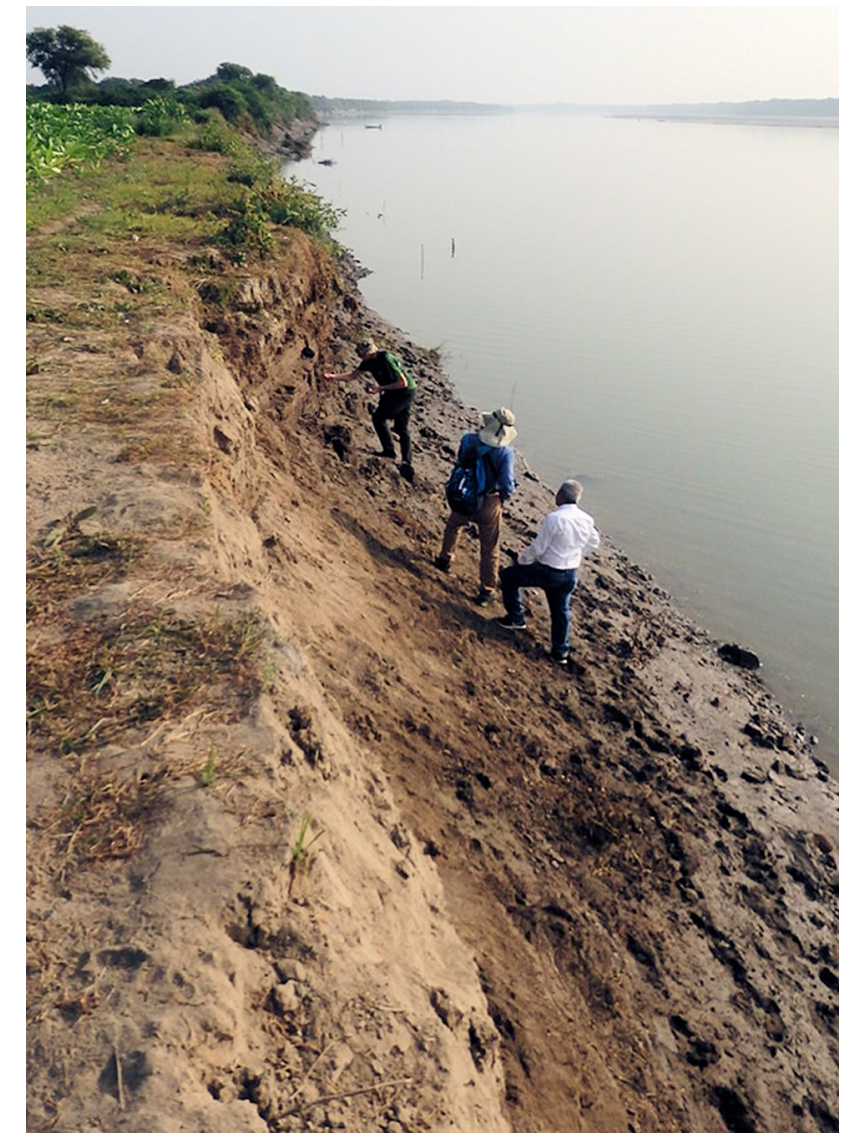

Fig. 4. Cliff section of a valley fill terrace on estuarine sediments at Kothiyakhad, showing alternate dark clays and silty sands 


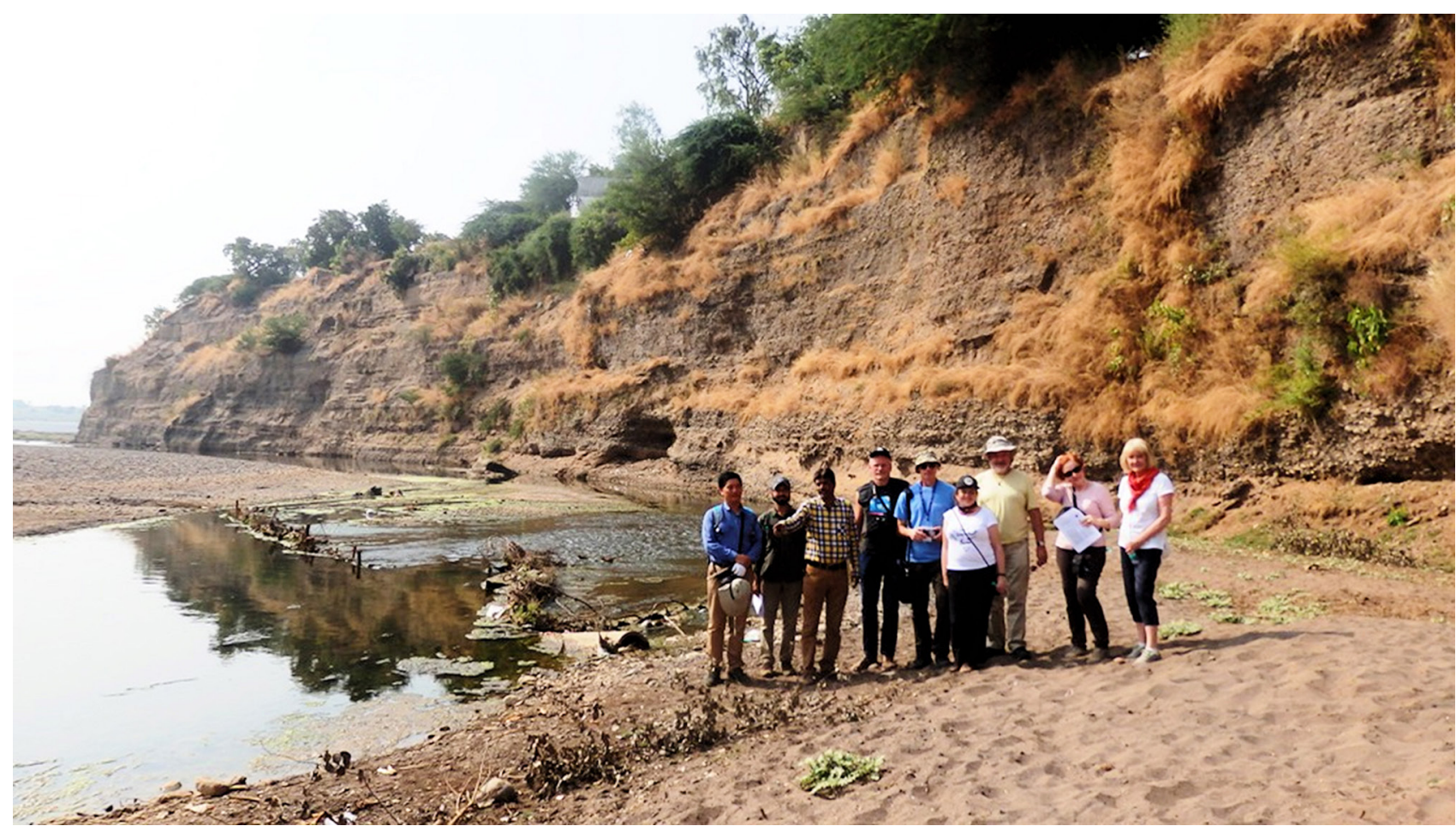

Fig. 5. Participants of the field trip on the background of deeply incised right bank at Tilakwada section showing alluvial fan sediments of Narmada river

From left to right: Xiu Ming Liu (China), D.M.Maurya's assistant, D.M. Maurya (India), Paweł Kotkowski (Poland), Piotr Gębica (Poland), Lucyna Wachecka-Kotkowska (Poland), Denes Loczy (Hungary), Julia Armas (Romania) and Hazel Faulkner (Great Britain).

As indicated by OSL dating, the bottom series of alluvium and the fossil soil can be correlated with MIS-4 and MIS-3, while the upper series with Last Glacial Maximum (LGM) (MIS-2) and Late Glacial. Occurrence of fluvioeolian sediments in the upper part of the sequence indicates a gradual transition from fluvial sedimentation into aeolian after about $30-25 \mathrm{ka}$ BP. The onset of aeolian activity is associated with a decrease in the SW monsoon circulation and a clear aridisation of the climate during the LGM. The lack of aeolian sediments in the Narmada outcrops and their presence in the Orsang river valley (the right-bank tributary of the Narmada) and in the Mahi valley suggest that the southern boundary of aeolian sediment accumulation during LGM was near the Narmada valley (Bhandari et al. 2005).

The problem of the formation of the flood plain in the estuary area of the Mahi River was discussed at the Kothiyakhad site, about $10 \mathrm{~km}$ from the mouth of the river to the Gulf of Cambay (November 13). The flood plain with a height of $4 \mathrm{~m}$ is built by fluvial and estuarine sediments. Radiocarbon dates indicate the Young Holocene age of sediments (3660-1760 BP), the accumulation of which is associated with a slow increase in sea level (marine transgression) in the last 4000 years. Occurrence of small folds, synsedimentary (micro) faults and load structures in the sediments of Holocene deposits, indicates that the deformation structures were formed as a result of seismic shocks (Maurya et al. 1998) (Fig. 4).

On the third day of excursion (November 14) we visited Tilakwada section, where the alluvial fan deposits occurs along the cliffy banks of the Narmada river (Fig. 5). At the foot of the Deccan Plateau in the deeply incised meandering trough of the side tributary of Narmada, deposits of a gravel piedmont fan (bajada) were revealed (Fig. 6). The altitude of the fan surface near the upland front is $120 \mathrm{~m}$ a.s.l. and it extends for about $24 \mathrm{~km}$ along the hill edge. The weakly rounded clasts of basalt, range in size from pebble to boulder found in the sandy-clay material

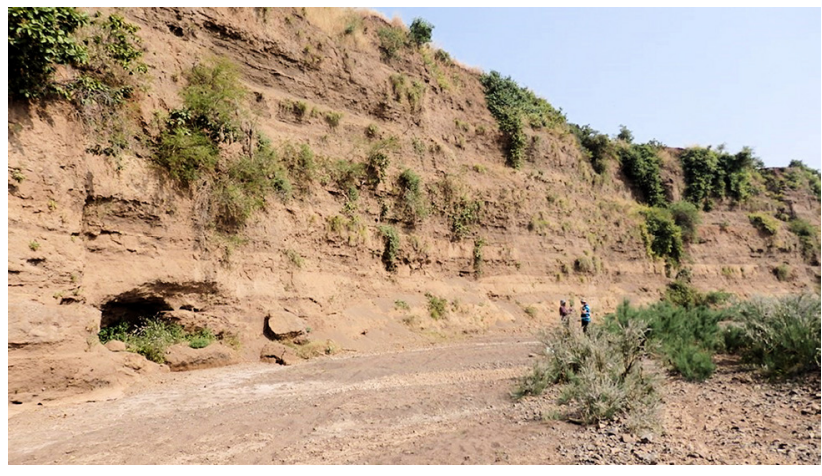

Fig. 6. View of the cliff exposing bajada sediments at the Nadhikhadi River Basin located on the edge of the Deccan Plateau with frequent occurrence of knick points, tight meanders and deeply incised channel segments 


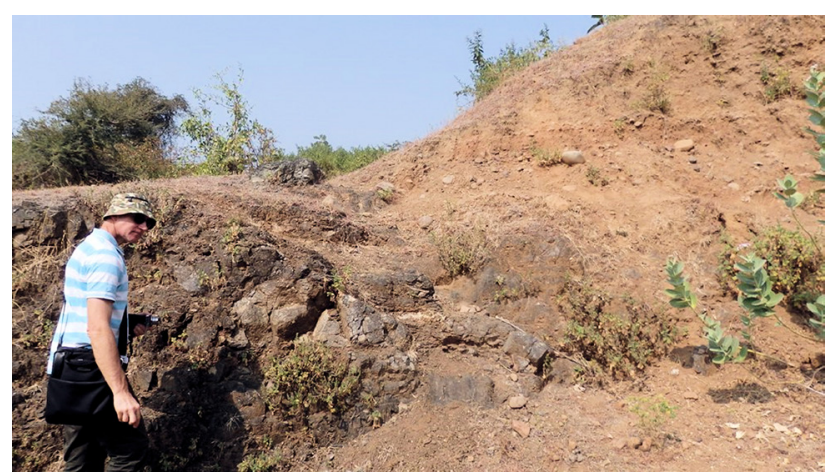

Fig. 7. The Narmada-Son Fault system within NW boundary of the Deccan basaltic trapp $\left(21^{\circ} 50^{\prime} \mathrm{N}, 73^{\circ} 30^{\prime} \mathrm{E}\right)$

Sharp contact between basalts and wedge shaped coarse gravelly bajada sediments in front of the plateau hills.

were deposited during debris flow at the foot of the tectonically active, established on the NSF fault, the edges of Trappean upland. The OSL dating of sandy sediments in the middle part of the bajada succession showed the age of $25 \mathrm{ka} \mathrm{BP}$, so the deposition of sediments took place in the Younger Pleniglacial (Fig. 6).

On the fourth day of the trip (November 15), in the Ranipura profile the results of the dating of the overbank sediments of the 5-meter high Holocene Terraces of Narmada was presented. These flood sediments (organic sands and silts), dated by radiocarbon method from approx. 2200-1310 BP, were accumulated in several phases of climate change related to the active impact of SW monsoon (Sridhar et al. 2015). On the other place, estuaries (silts and clays laminated with sands) containing marine foraminifera (Chamyal et al. 2002) were observed in a 10-meter high Holocene terrace (Tavra profile), about $10 \mathrm{~km}$ from the mouth of the Narmada River to the Gulf of Cambay. In the estuary section the sedimentation of marine deposits was generated by the tides, which amplitude reached 12-15 meters. Upstream of the river, outside the estuary, there is a similar height terrace, but built of sandy river sediments.

An attractive site on the last day of the trip (November 16) was a trip to the Deccan Plateau, where we got acquainted with the morphology of the terrain and structure of terraces in the Karjan River valley
(Narmada tributary), founded on an active tectonic fault. At the intersection of the NSF fault with the Karjan River fault, a dam was built. Exposed in the valley, the sand and gravel sediments have a thickness of $15 \mathrm{~m}$ and build a terrace 58 meters above the river bed. Alluvium lies on the strongly weathered strata of the basalt trapp (Fig. 7), which show a significant slope resulting from a tectonic uplift. Dating of alluvial sediments using OSL method showed that the age of the upper part of sand cover is approx. $33 \mathrm{ka} \mathrm{BP}$, and therefore the sediments represent the Pleniglacial period (MIS-3). The high position of the terrace strata and the considerable incision of the Karjan river bed are the result of intense tectonic uplifting, which is believed to have taken place in the Early Holocene and reached the value of $40 \mathrm{~m}$ (Chamyal et al. 2002).

\section{Selected references}

Bhandari S., Maurya D.M., Chamyal L.S., 2005. Late Pleistocene alluvial plain sedimentation in Lower Narmada Valley, Western India: Palaeoenvironmental implications. Journal of Asian Earth Sciences 24: 433-444.

Chamyal L.S., Maurya D.M., 2017. B6: Geomorphological Field Guide Book on Semi-arid Gujarat Alluvial Plain. A.Kar (ed.), Indian Institute of Geomorphologists, Allahabad: 1-76.

Chamyal L.S., Maurya D.M., Bhandari S., and Raj R., 2002. Late Quaternary geomorphic evolution of Lower Narmada Valley, western India: Implications for neotectonic movements along the Narmada-Son Fault. Geomorphology 46: 177-202.

Joshi P.N., Maurya D.M., Chamyal L.S., 2013. Morphotectonic segmentation and spatial variability of neotectonic activity along the Narmada-Son Fault, Western India: Remote sensing and GIS analysis. Geomorphology 181-182: 292-306.

Maurya D.M., Chamyal L.S., and Merh S.S., 1995. Tectonic evolution of central Gujarat alluvial plain, Western India. Current Science 69: 610-613.

Maurya D.M., Raj R., and Chamyal L.S., 1998. Seismically induced deformational structures from Mid-Late Holocene terraces in the lower Mahi valley, Gujarat. Journal of the Geological Society of India 51: 755-758.

Sridhar A., Laskar A., Prasad V., Sharma A., Tripathi J., Balaji D. Maurya D.M., and Chamyal L.S., 2015. Late Holocene flooding history of tropical river in western India in response to southwest monsoons fluctuations: A multi-proxy study from lower Narmada valley. Quaternary International 37: 181-190. 